\title{
Is There Impact of the SARS-CoV-2 Pandemic on Steroidogenesis and Fertility?
}

\author{
Nikola KNÍŽATOVÁ ${ }^{1}$, Martin MASSÁNYI ${ }^{2}$, Shubhadeep ROYCHOUDHURY ${ }^{\mathbf{3}}$, Pokhraj \\ GUHA $^{4}$, Hana GREIFOVÁ ${ }^{1}$, Katarína TOKÁROVÁ ${ }^{1}$, Tomáš JAMBOR ${ }^{5}$, Peter \\ MASSÁNYI ${ }^{1}$, Norbert LUKÁĆ ${ }^{1}$
}

${ }^{1}$ Institute of Applied Biology, Faculty of Biotechnology and Food Sciences, Slovak University of Agriculture in Nitra, Nitra, Slovak Republic, ${ }^{2}$ AgroBiotech Research Centre, Faculty of Biotechnology and Food Resources, Slovak University of Agriculture in Nitra, Nitra, Slovak Republic, ${ }^{3}$ Department of Life Science and Bioinformatics, Assam University, Silchar, India, ${ }^{4}$ Department of Zoology, Garhbeta College, Paschim Medinipur, India, ${ }^{5}$ BioFood Centre, Faculty of Biotechnology and Food Sciences, Slovak University of Agriculture in Nitra, Nitra, Slovak

Republic

Received July 7, 2021

Accepted August 10, 2021

\section{Summary}

In December of 2019, several cases of unknown atypical respiratory diseases emerged in Wuhan, Hubei Province in China. After preliminary research, it was stated that the disease is transmittable between humans and was named COVID-19. Over the course of next months, it spread all over the world by air and sea transport and caused a global pandemic which affects life of everyone now-a-days. A large number of countries, have since been forced to take precautions such as curfews, lockdowns, wearing facemasks etc. Even with vaccines being produced in mass numbers, lack of targeted therapy continues to be a major problem. According to studies so far it seems that elderly people are more vulnerable to severe symptoms while children tend to by asymptomatic or have milder form the disease. In our review, we focused on gathering data about the virus itself, its characteristics, paths of transmission, and its effect on hormone production and secretion. In such, there is insufficient information in the literature worldwide, especially the ones that focus on the effect of COVID-19 on individual organs systems within the human body. Hence, the present evidence-based study focused on the possible effects of COVID-19 on adrenal gland and gonads i.e. on the process of steroidogenesis and fertility.

\section{Key words}

Adrenal gland • ACE2 • COVID-19 • Fertility • SARS-CoV-2 • Steroidogenesis • TMPRSS2

\section{Corresponding author}

N. Knížatová, Institute of Applied Biology, Faculty of Biotechnology and Food Sciences, Slovak University of Agriculture in Nitra, Tr. A. Hlinku 2, 94976 Nitra, Slovak Republic. E-mail: nikola.knizatova@gmail.com

\section{Introduction}

In Wuhan, Hubei Province, China, patients with an atypical type of pneumonia were diagnosed during the second week of December 2019. It was detected as a new coronavirus at this time, initially called nCoV-2019 (Ghaebi et al. 2020). In mid-January, with its specific description of "severe acute respiratory syndrome coronavirus 2" (SARS-CoV-2), thus labeled as "Coronavirus disease 2019" (COVID-19), the genome of this pathogen was made public. This virus has spread rapidly worldwide and across mainland China, as of 10 August 2021, there have been 202608306 confirmed cases, including 4293591 deaths (WHO 2021c). The World Health Organization announced a pandemic state 
for the entire world on March 11 (Bhagavathula et al. 2020, Silveira et al. 2021). SARS-CoV-2 is considered a public health issue as transmission rates are shown to be higher than other coronaviruses, primarily due to the risk of overloading intensive care units, thereby causing health systems to collapse (Silveira et al. 2021). In this review, we will focus on the virological features and pathogenesis of SARS-CoV-2, as well as diagnostic tools and, of course, possible impact on steroidogenesis.

\section{Viral transmission}

Viral infections are nowadays becoming an extremely serious issues to the public health. During last two decades, viral epidemics, including SARS-CoV (Severe Acute Respiratory Syndrome) which emerged in 2002-2003 with a case fatality rate (CFR) of $10 \%$ (van Damme et al. 2020) and H1N1 influenza in 2009 have been recorded. MERS-CoV (Middle East Respiratory Syndrome coronavirus) has been the latest recorded epidemic, that emerged in Saudi Arabia (2012) (CFR $34 \%$ ) (Cascella et al. 2021, van Damme et al. 2020, WHO 2021b).

The First case of COVID-19 was detected in Wuhan, Hubei province, China on 31. December 2019. The etiology of this illness was attributed to a novel virus of coronavirus (CoV) family, SARS-CoV2 (Cascella et al. 2021). Soon after its identification, it became clear to the epidemiologists worldwide that its global spread was unstoppable. Stringent containment approaches including strict movement restrictions during the "lockdown", failed to restrict its spread. As a result, owing to its rapid uncontrolled outbreak in almost all countries within a few months, COVID-19 was declared a pandemic by the WHO (van Damme et al. 2020). Currently, entire world is afflicted by COVID-19 pandemic.

Infection spreading from bats, was the first marked as the possible origin of the disease (Fan et al. 2019), though to this day this has not been officially confirmed as the source of the first infection. No international preventive action was taken and the first details about the epidemic was released by National Health Commission of China in early 2020 (Lotfi et al. 2020).

COVID-19 occurs mainly in respiratory (nasal), fecal and blood samples of infected. Inhalation of droplets as well as contact with contaminated surfaces were discovered to be the main routes of transmission. It is expected to survive on various surfaces for extended periods of time. Similar as per influenza, wide expectations are that the virus will decrease with activity as the weather warms up during summer due to higher temperatures and increased exposure to UV rays (Esakandari et al. 2020).

Multiple precautions are currently in effect worldwide. Including global cure effort, lockdowns, curfews and use of disinfectants and face masks to prevent contact with face and respiratory tract are recommended.

\section{Characteristics of SARS-CoV-2}

The virus is single stranded $29.9 \mathrm{~kb}$ RNA $\beta$-coronavirus that is enveloped and positive-sense ( $\mathrm{Wu}$ et al. 2020, Zhou et al. 2020). Further investigation of the viruses' genome shown $88 \%$ similarity with the bat-SLCoVZC45 and bat-SL-CoVZXC21 sequences as well as over $96 \%$ identity to bat CoV RaTG13 (Zhou et al. 2020). It has also been related to Malayan or Sunda pangolins in China (Lam et al. 2020). The protein-coding genes of COVID-19 have $79.5 \%$ and $51 \%$ similarities in sequence to SARS-CoV and MERS-CoV respectively (Lotfi et al. 2020). Similar to SARS-CoV, the virus employs Angiotensin-Converting Enzyme 2 (ACE2) receptor for cellular entry (Guo et al. 2020, Paces et al. 2020, Paraskevis et al. 2020, Zhou et al. 2020). This suggests that methods used to treat SARS-CoV and MERS-CoV might be also effective against COVID-19, although currently, there is no definite antiviral therapy developed for treating SARS-CoV-2 infection (Jha et al. 2021, Lotfi et al. 2020, Roychoudhury et al. 2021a). Given the frequent emergence of viral pandemics in the 21 st century, proper understanding of their characteristics and modes of action are essential to address the immediate and long-term health consequences (Roychoudhury et al. 2020, Vašků 2020).

SARS-CoV-2 belongs to the beta coronavirus family as that of extremely pathogenic viruses such as SARS-CoV and MERS-CoV. It is a positive-sense singlestranded RNA (+ssRNA) and an enveloped virus. SARSCoV-2 is regarded as a novel beta coronavirus infecting humans (Burrell et al. 2021, Jha et al. 2021). Although, the novel coronavirus has genetic features that are compatible with the family of coronaviruses it also has gene sequences different to already sequenced coronaviruses (He et al. 2020).

The most common symptoms of the disease are 
fever, dry cough and tiredness. Less common symptoms are various aches and pains, sore throat, diarrhea, conjunctivitis, headache, loss of senses (taste, smell), skin rash or discoloration. It also causes serious symptoms such as difficulties in breathing or breath shortness, chest pain, loss of speech and movement (WHO 2021a).

\section{Role of Angiotensin converting enzyme 2 and transmembrane protease, serine 2}

Angiotensin converting enzyme 2 (ACE2) belongs to the dipeptidyl carboxydipeptidase family of angiotensin converting enzymes that are homologous to the human angiotensin 1 converting enzyme. Recently, it has been identified as a potent receptor for SARS-CoV, indicating connections of ACE2 with immunity, inflammation, and cardiovascular diseases (Gheblawi et al. 2020). The distribution of ACE2 expression was organ-specific, predominantly in the kidney, male testis, female breast, cardiovascular and gastrointestinal systems and adrenocortical cells in zona fasciculata and zona reticularis (Fu et al. 2020, Mao et al. 2021). Table 1 contains information on tissues showing ACE2 expression. A rank list of possible SARS-CoV-2 targets with lung AT2 cell (Alveolar Type II Cells) and macrophages as the top targets, followed by cardiomyocytes of heart, stromal cells in testis, ovary, adrenal, and thyroid glands. Among the above mentioned possible targets, the lung macrophages and the stromal cells in ovary and adrenal gland were identified for the first time, which could account for extreme clinical symptoms and rapid disease progression (Bost et al. 2020). The distribution of ACE2 expressions indicates that it may play a critical role in controlling cardiovascular and renal function, as well as fertility. Numerous studies have revealed the role of cell surface ACE2 as the cellular receptor for SARS-CoV and NL63 (Human coronavirus NL63) since the global outbreak of SARS in 2003. As 2019-nCoV is closely related to SARS-CoV, ACE2 has also been shown to be a major receptor of the novel 2019-nCoV (He et al. 2020, Li et al. 2007, Wu et al. 2009). The route of virus infection depends on the expression and distribution of the corresponding receptor as the virus reaches the cell by binding to cell surface receptors in order to complete intracellular replication, virus release, and other related cytotoxic activities (Fan et al. 2019, Jayawardena et al. 2019). SARS-spike CoV-2's glycoprotein (S protein) is necessary for binding to the host ACE2 receptor and membrane fusion. The conformational aspects of the interaction of the RBD (receptor-binding domain) of $S$ protein with ACE2 have been elucidated by structural studies (Simmons et al. 2013, Walls et al. 2020, Wang et al. 2020a, Wang et al. 2020b). This binding triggers conformational changes in amino acids, which assist in the formation of salt bridges, the increase of van der Waals interactions, and the binding of ACE2 with a much higher affinity than SARS-CoV (Yan et al. 2020). Subunit S1 with the RBD that binds ACE2, membranefusion subunit $\mathrm{S} 2$, the transmembrane anchor, and the intracellular tail make up the S protein (Glowacka et al. 2011, Hoffmann et al. 2020, Wrapp et al. 2020). Recent studies have documented 10 to 20 fold higher binding affinity of the spike glycoprotein of the SARS-CoV-2 to ACE2 than that of SARS-CoV (Ni et al. 2020, Wrapp et al. 2020).

Transmembrane serine protease 2 (TMPRSS2) is a cell surface protein primarily expressed by endothelial cells of the respiratory and digestive tract. As a serine protease, it is involved in cleaving peptide bonds of proteins that have serine as the nucleophilic amino acid within the active site (Hoffmann et al. 2020). The cellular transmembrane protease serine S1 member 2 (TMPRSS2) is needed to cleave S2 protein from S1 and assist in membrane fusion in order for the receptor binding domain (RBD) of $\mathrm{S} 1$ to attach to the host ACE2 receptor. SARS-CoV-214 has a 10- to 20-fold higher receptorbinding ability than SARS-CoV and MERS-CoV due to certain special features of the S1 protein (Wrapp et al. 2020). TMPRSS2 serine protease was co-localized in adrenocortical cells in zona fasciculata and zona reticularis Mao et al. 2021, in certain testicle cells - stem germ cells, Leydig and Sertoli cells (Navarra et al. 2020), in kidney, lungs, stomach, liver and pancreas (Lü et al. 2020). Table 1 contains information on tissues showing TMPRSS2 expression. TMPRSS2 gene has a pivotal role also in prostate cancer development and progression (Mollica et al. 2020). In a recent study based on gene co-expression of ACE2 and TMPRSS2 in 24,519 human prostate cells, it was found that the $0.61 \%$ of club cells and the $0.40 \%$ of hillock cells showed co-expressions for TMPRSS2 and ACE2 (Song et al. 2020). The authors also reported higher TMPRSS2 and ACE2 co-expression in males pneumocytes I/II compared with female cells, representing an interesting evidence which could play a role in gender 'pattern' of COVID-19.

In another recent study, Prostate cancer patients receiving androgen deprivation therapy (ADT) had 
a significantly lower risk of SARS-CoV-2 infection compared with patients who did not receive ADT (odds ratio: $4.05 ; 95 \% \mathrm{CI}: 1.55-10.59$ ). This study sets the scenario for further studies assessing the role of antiandrogens commonly used for prostate cancer patients to prevent or treat COVID-19 (Montopoli et al. 2020).

Table 1. Pathophysiology of SARS-CoV-2 infection on the male reproductive system, female reproductive system and adrenal gland.

\begin{tabular}{|c|c|c|c|}
\hline \multirow{2}{*}{$\begin{array}{l}\text { Tissues showing } \\
\text { expression }\end{array}$} & ACE2 & $\begin{array}{l}\text { Ovary, oocytes, uterus, placenta, } \\
\text { seminiferous tubule, Leydig cells, } \\
\text { Sertoli cells, spermatozoa, adrenal gland }\end{array}$ & $\begin{array}{l}\text { Dutta and Sengupta } 2020 \text {, } \\
\text { Jing et al. 2020, Lü et al. } \\
\text { 2020, Stanley et al. } 2020\end{array}$ \\
\hline & TMPRSS2 & $\begin{array}{l}\text { Ovary, epididymis, prostate gland, } \\
\text { seminal vesicles, adrenal gland }\end{array}$ & $\begin{array}{l}\text { Dutta and Sengupta } 2020 \text {, } \\
\text { Jing et al. 2020, Lü et al. } \\
\text { 2020, Stanley et al. } 2020\end{array}$ \\
\hline
\end{tabular}

Possible effect on adrenal gland

Possible effect on male reproductive system

Possible effect on female reproductive system
Adrenal lesions, necrosis, cortical lipid degeneration, hemorrhage, unspecific focal adrenalitis
Freire Santana et al. 2020

Pathological changes in testes, reduction of Leydig cells, orchitis, affected semen parameters (such as sperm function and motility), lipid peroxidation; and DNA damage due Duarte-Neto et al. 2020, Dutta and Sengupta 2021, Holtmann et al. 2020, Yang et al. 2020 to oxidative stress

\section{Menstrual cycle changes, ovarian} tissue damage, decrease in ovarian function and oocyte quality
Lü et al. 2020, Singh et al. 2020

\section{SARS CoV-2 effect in the adrenal gland}

SARS-key CoV's, just like the influenza virus, uses immunoinvasive tactics to knock down the cortisol stress response of the host. The SARS-CoV expression of certain amino acid sequences, which are molecular mimics of the host adrenocorticotropic hormone (ACTH), is a very fascinating hypothesis that has been suggested. The stressinduced increase in cortisol can also blunt this type of molecular mimicry, as antibodies produced against the viral particles will inadvertently kill the circulating ACTH, and so limiting the host's stress response (Wheatland 2004). The fact that most SARS-CoV-2 proteins are extremely homologous (95-100\%) to the original SARS$\mathrm{CoV}$ proteins makes us wonder if SARS-CoV-2 might also use the same molecular mimicry strategy (Pal and Banerjee 2020, Xu et al. 2020). Patients with extreme COVID-19 could also be more likely to experience critical corticosteroid-related disease insufficiency (CIRCI).
However, data on the dynamics of cortisol in patients with COVID-19 is not yet available (Akbas and Akbas 2021, Pal and Banerjee 2020). Information from the SARS outbreak indicates that the hypothalamic-pituitary-adrenal (HPA) axis could be affected by this disease (possibly also COVID-19) (Akbas and Akbas 2021).

Hypothalamic tissues and pituitary tissues express ACE2, allowing SARS-CoV-2 to target these tissues. While we do not have adequate evidence for now, given the neurological symptoms, it can be thought that COVID-19 directly or immune-mediated hypothalamus and pituitary are affected (Akbas and Akbas 2021, Pal and Banerjee 2020). Degeneration and necrosis of adrenal cortical cells were shown by autopsy findings in patients who died from SARS, suggesting a direct cytopathic effect of the virus. Besides, in the adrenal glands, viral antigens and the genomic sequence of SARS-CoV have been demonstrated. Therefore, cortisol dynamics are likely to be altered in patients with SARS (and probably 
also with COVID-19) (Ding et al. 2003, Gu and Korteweg 2007). Therefore, cortisol dynamics are likely to be altered in patients with SARS (and possibly also patients with the occurrence of COVID-19). Similarly, $46 \%$ of patients in whom adrenal insufficiency was not found had microscopic lesions in the adrenal glands detected in 28 autopsies with reported SARS-CoV-2 infection. The microscopic findings reported in these cases are unspecific focal adrenalitis, necrosis, lipid degeneration, vascular thrombosis, hemorrhage, and focal inflammation (Freire Santana et al. 2020).

Immunohistochemical staining of ACE2 in human adrenal gland sections showed no obvious immunoreactivity in the zona glomerulosa, which is the unique source of the mineralocorticoid aldosterone. In contrast, ACE2 was widely distributed in the zona fasciculata/reticularis, which produces glucocorticoids and androgens. Transmembrane Serine Protease 2 (TMPRSS2) appears to prime the viral spike (S) protein to enhance ACE2-mediated SARS-CoV-2 entry. TMPRSS2 was widely expressed in all three zones of the adrenal cortex (Hoffmann et al. 2020, Mao et al. 2021, Yang et al. 2020). This finding was further confirmed by the co-localization of ACE2 or TMPRSS2 with CYP11B1, a marker for the functional differentiation of cells in the zona fasciculata and reticularis. These results suggest that SARS-CoV-2 may potentially directly target zona fasciculata/reticularis of the adrenal cortex, thereby influencing circulating glucocorticoid levels (Mao et al. 2021). Vanderriele et al. (2018) strongly demonstrated the presence of ACE, and ACE2 in H295R and HAC15 cells, therefore these cells may be considered as a useful in vitro model for the investigation of effects on steroid hormone synthesis, specifically the production of $17 \beta$-estradiol and testosterone.

Although data on COVID-19-mediated modulations in cortisol dynamics are yet not available, the glucocorticoid insufficiency (specifically cortisol) may disrupt the HPA-HPT crosstalk during stress-loaded situations and will not affect testosterone and LH production (Sengupta and Dutta 2021). Thus, it also suggests HPT-independent testosterone downregulation by SARS-CoV-2 infection (Dutta and Sengupta 2020).

As per recent findings, the possibility of venous thrombo-embolism in COVID-19 patients have been indicated and its favorable treatment by heparin in some of them. Thus, it can be assumed that an acute adrenal insufficiency in COVID-19 patients may also be due to a thrombotic event at the adrenal level. This could result in impaired hormone production with consequent shock and worsening of the possibility of reacting to severe respiratory distress (Bellastella et al. 2020).

Furthermore, patients with chronic glucocorticoid (GC) excess may be at high risk of developing COVID-19 infection with a severe clinical course (Guarnotta et al. 2020). Table 1 and Figure 1 provide additional information on the possible effects of SARS-CoV-2 on the adrenal gland.

\section{SARS-CoV-2 effect in the testis}

In addition to respiratory symptoms, COVID-19 patients have been reported to have multi-system complications, such as cardiovascular and digestive system problems. One potential mechanism may be that the pathogen that causes COVID-19, severe acute respiratory syndrome coronavirus (SARS-CoV-2), enters cells through its receptor, angiotensin-converting enzyme-2 (ACE2), this virus may therefore invade organs with a high expression of ACE2 (Guan et al. 2020, Hoffmann et al. 2020, Zhang et al. 2020a, Zhang et al. 2020b). In adult male Leydig testis cells, ACE2 has been reported to be highly expressed, and male COVID-19 patients have been reported to have abnormal sex hormone concentrations compared to healthy men (Douglas et al. 2004, Ma et al. 2020), indicating that viral infection may injure male reproductive endocrine function.

In the male reproductive system, the testis, primarily due to its elevated ACE2 expression levels, should probably be the organ most vulnerable to SARSCoV-2 infection. In spermatogonia, seminiferous tubules, Sertoli and Leydig cells, ACE2 receptors are present (Chen et al. 2020, Fan et al. 2021). Over damage to the testis, spermatozoa, abnormal sex hormone expression, and inflammatory cytokine dysregulation are the deleterious consequences of viruses (Gupta et al. 2021, Puggioni et al. 2018). It has been shown that testicular expression of ACE2 is age-related. The highest level of expression has been identified in patients aged 30 and older than 20, whereas those aged 60 have the lowest level of expression (Shen et al. 2020). That may suggest that, because of COVID-19, young male patients are more likely to experience a testicular injury than older patients. This also indicates the profound pathophysiological role of different hormonal environments in male infection with SARS-CoV-2 (Dutta and Sengupta 2020, Roychoudhury et al. 2021a). 


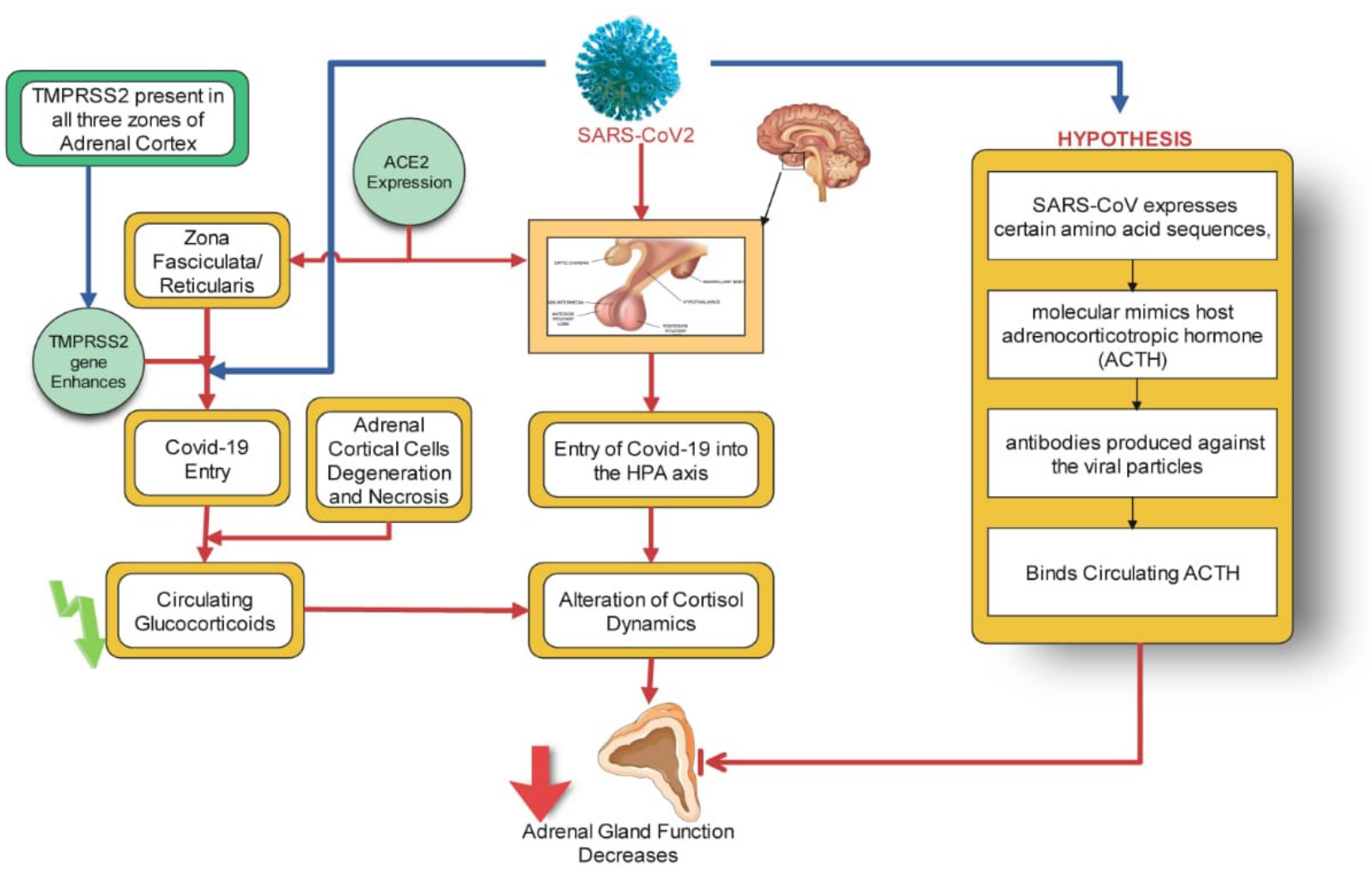

Fig. 1. Possible effect of SARS-CoV-2 on adrenal gland. SARS-CoV-2: severe acute respiratory syndrome coronavirus 2; TMPRSS2: transmembrane protease/serine subfamily member 2; ACE2: angiotensin-converting enzyme 2; ACTH: Adrenocorticotropic hormone; HPA axis: hypothalamic-pituitary-adrenal axis.

Steroidogenesis is one of the main functions of the testes. As a result, monitoring sex hormone levels could be used to determine gonadal function in COVID19 patients (Madjunkov et al. 2020). In a study comparing the hormone levels of 119 infected men with 273 age-matched control subjects, the effect of SARS-CoV-2 infection on testicular hormonal function was evaluated. In the infected group, the authors found a significant increase in the levels of luteinizing hormone (LH) and a concomitant decrease in the ratio of serum total testosterone/luteinizing hormone (T/LH). C-reactive protein and white blood cell count were negatively correlated with the T/LH ratio, likely by injury to Leydig cells, meaning an early transient hypogonadism stage (Ma et al. 2020). Nonetheless, COVID-19 may have temporary or permanent detrimental effects on male reproduction. It may involve endocrine alterations in LH and testosterone (Wang et al. 2020, Wang et al. 2020). In men with COVID-19, elevated serum LH negates the possibility of hypothalamic-pituitary-testicular axis suppression and hints of primary damage to Leydig cells. It is to be noted that orchitis was also a recognized complication of SARS (Xu et al. 2006). Rastrelli et al.
(2021) investigated hormone levels in male patients admitted to the respiratory intensive care unit (ICU) with SARS-CoV-2. Worsening of clinical status was coupled with a progressive reduction in $\mathrm{T}$ levels and increase in LH levels. However, these results should be interpreted with caution, since the sex hormone baseline in these patients before infection was not available. Besides, SARS-CoV infection was shown to significantly reduce serum testosterone in male mice (Channappanavar et al. 2017). Although more research is required to determine the reasons and underlying mechanisms, findings show irregular sex hormone secretion in COVID-19 patients, implying that reproductive function should be evaluated during follow-up (Ma et al. 2020).

There are conflicting reports SARS-CoV-2 infection in male specimens contributes to acute stage hypogonadism and it is suggested that even fatal consequences can result from a decrease in androgenic action. Several human and animal studies have related hypogonadism to increased levels of pro-inflammatory cytokines, primarily IL-1 $\beta$, IL-6, and TNF- $\alpha$, which are essential inflammatory mediators in the pathogenesis of SARS-CoV-2. Nonetheless, as in the case of COVID-19, 
an acute critical inflammatory condition can suppress hypothalamic-pituitary-testicular (HPT) axis activity, resulting in reduced levels of low luteinizing hormone (LH), follicle-stimulating hormone (FSH), and testosterone (Dutta and Sengupta 2020, Ma et al. 2020, Maggio et al. 2005, Mohamad et al. 2019, Pozzilli and Lenzi 2020). However, this theoretical perception does not correlate to a study conducted in 81 male COVID-19 patients that recorded lower serum testosterone levels, higher LH levels, and lower T:LH ratios compared to control subjects matched by age. These findings can indicate direct effects of SARS-CoV-2 infection rather than through the HPT axis in testicular cells (Ma et al. 2020). Therefore, the interactions of male SARS-CoV-2 infection and sex hormone regulation are significant missing links that await in-depth investigation (Dutta and Sengupta 2020). Besides the direct relation of SARSCoV-2 infection and oxidative stress (OS), treatment of COVID-19 includes antiviral drugs like ribavirin which is associated with induction of OS, reduced testosterone level, impaired spermatogenesis, and sperm abnormalities in animal studies (Almasry et al. 2017, Narayana et al. 2002).

Sengupta and Dutta (2021) explained possible mechanisms of SARS-CoV-2 infection mediated testosterone depletion. Androgen receptor and ACE2 are located in chromosome-X, while androgen receptor activation is needed to trigger TMPRSS2 gene transcription, aiding SARS-CoV-2 entry into host cells. SARS-CoV-2 infection triggers inflammatory responses and oxidative stress-mediated disruptions of Leydig cell functions. Advanced age, psychological, and other comorbidities associated with COVID-19 may also lead to oxidative stress. Viral amino acids may mimic ACTH molecules and stimulate production of antibodies against host $\mathrm{ACTH}$, thereby reducing glucocorticoid levels and suppressing host response to combat stress. Hypothalamic-pituitary-testicular (HPT) axis may not be affected by SARS-CoV-2 infection, thus due to low testosterone level, LH level remains high in COVID-19 patients (Sengupta and Dutta, 2021). COVID-19 is a worry for couples trying to conceive. After binding with ACE2-positive cells, SARS-CoV-2 penetrate within the testes that could become a viral reservoir (Barbagallo et al. 2020, Cardona Maya et al. 2020). Table 1 and Figure 3 provide additional information on the possible effects of SARS-CoV-2 on the male reproductive system.

\section{SARS-CoV-2 effect on the ovary}

Females are less vulnerable to COVID-19. Epidemiological studies have shown that males account for most COVID-19 casualties, but only marginally more likely to be infected than females (Zhang et al. 2020a, Zhang et al. 2020b). In the largest survey of 72,314 suspected or confirmed cases of COVID-19 in China (men, $63.8 \%$ of cases; women, $36.2 \%$ of cases), the case-fatality ratio was higher among men $(2.8 \%)$ than among women (1.7\%) (Griffith et al. 2020). Furthermore, compared to men without comorbidities, male patients with comorbidities have a higher risk of having critically ill status, although there is no such correlation in women (Meng et al. 2020). The female reproductive hormones, estrogen, and progesterone, down-regulate ACE. Some evidence also supports the notion that through direct antiviral activity and immunemediated mechanisms, estrogens and progesterone could exert a protective effect on women, thereby explaining the greater severity of COVID-19 in post-menopausal women (Cattrini et al. 2020). As previously mentioned, not only an exacerbated inflammatory reaction but also a hypercoagulable condition characterizes COVID-19 pathophysiology. Estrogen has been shown to decrease platelet aggregation and thrombus formation in animal models, while androgens improve them. This also tends to apply in humans under conditions of normal levels of estrogen exposure since the risk of thromboembolism is higher in males during the life cycle, while the risk of females throughout their fertile years is lowest, steadily increasing throughout menopause (Pivonello et al. 2020).

ACE2 expression was recorded in ovarian granulosa cells in a previous animal study (HonoratoSampaio et al. 2012), which suggests that the ovary may also become a target of SARS-CoV-2. Li et al. (2021) detected serum testosterone, oestradiol, progesterone, LH, FSH, and AMH by electrochemiluminescent immunoassays. According to their research, average sex hormone concentrations and ovarian reserve did not change significantly in COVID-19 women of childbearing age in comparison with those of age-matched controls. No previous study has evaluated the impact of COVID-19 on female sex hormones, therefore this is thought to be the first study focusing on clinical and laboratory findings, and especially sex hormones. A further study of sex hormone changes was conducted in 91 patients during the illness. The results revealed no statistically significant variations between the COVID-19 
patients and the controls in all the sex hormone concentrations. However, some patients experienced abnormal changes in their levels of sex hormones, such as inappropriately high FSH and LH levels during the early follicular period, which may imply ovarian suppression in these patients (Li et al. 2021). In females, a severe acute COVID-19 illness can disrupt the hypothalamic-pituitarygonadal (HPG) axis, lowering endogenous estrogens and progesterone production (Mauvais-Jarvis et al. 2020).

Furthermore, the treatment procedure affects the female hypothalamic-gonadal axis (Kao et al. 2019). In certain conditions, glucocorticoid therapy can be effective if its effect on the reproductive and endocrine system in women of reproductive age is not yet understood. There is currently no clinical evidence available regarding the effects of COVID-19 on the ovarian function of women of reproductive age. Female reproductive health has become increasingly important over the last decade, and there has been a global need to pay attention to the impact of COVID-19 on the reproductive system. Clinical research is therefore urgently needed to confirm whether COVID-19 viral infection causes endocrine disorders and damage to the ovaries in women of childbearing age (Li et al. 2021).

Women with Polycystic Ovary Syndrome (PCOS) are considered to typically belong to an age and sex group which is at lower risk for severe COVID-19. However, current evidences link the risk of severe COVID-19 with certain factors such as hyperinflammation, ethnicity predisposition, low vitamin D levels, and hyperandrogenism, all of which have known direct associations with PCOS. This strong overlap of risk factors for both worse PCOS cardio-metabolic manifestations and severe COVID-19 should be highlighted for proper management of PCOS patients (Kyrou et al. 2020). Table 1 and Figure 2 provide additional information on the possible effects of SARS$\mathrm{CoV}-2$ on the female reproductive system.

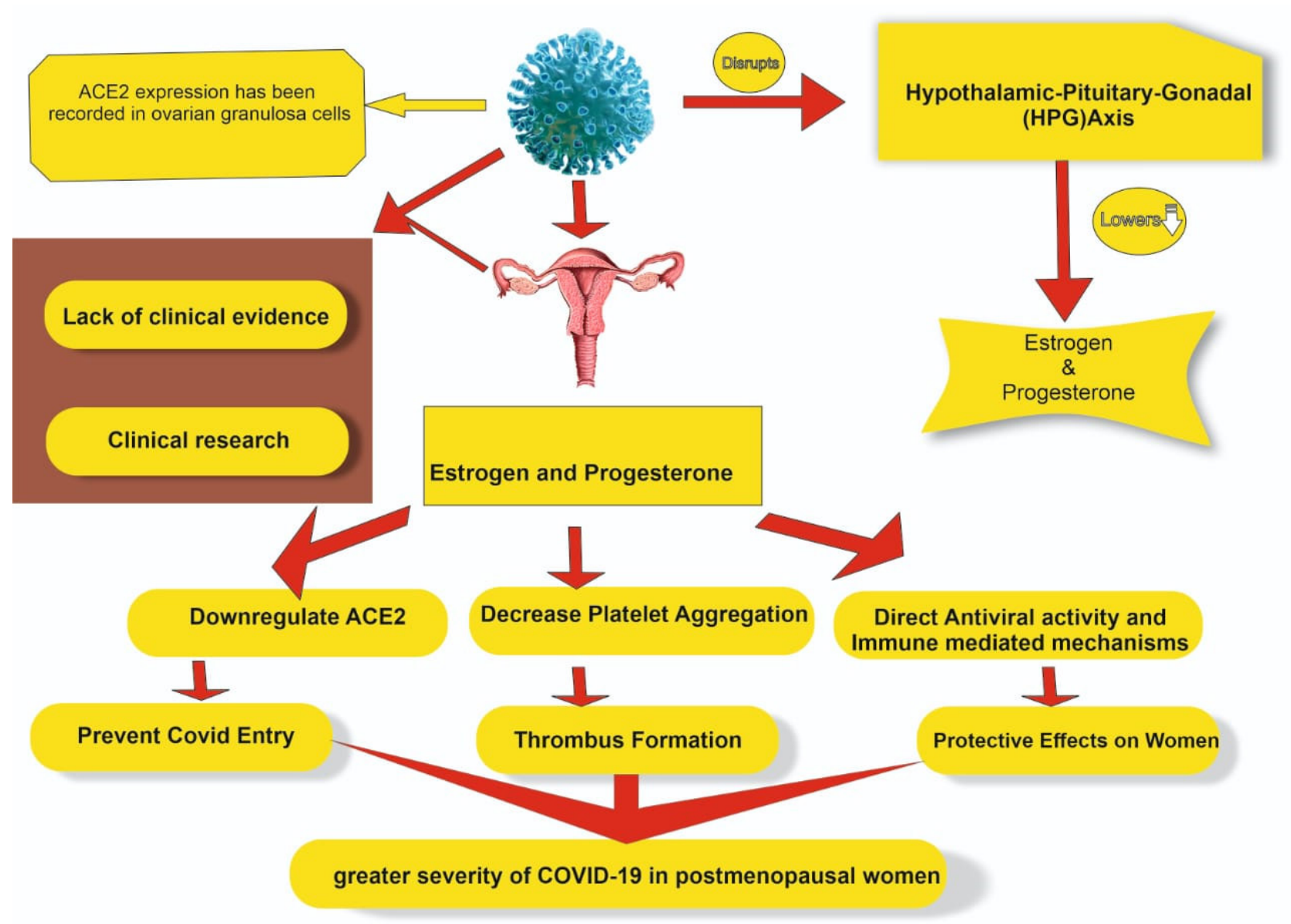

Fig. 2. Possible effect of SARS-CoV-2 on the female reproductive system. ACE2: angiotensin-converting enzyme 2; HPG axis: hypothalamic-pituitary-gonadal axis. 


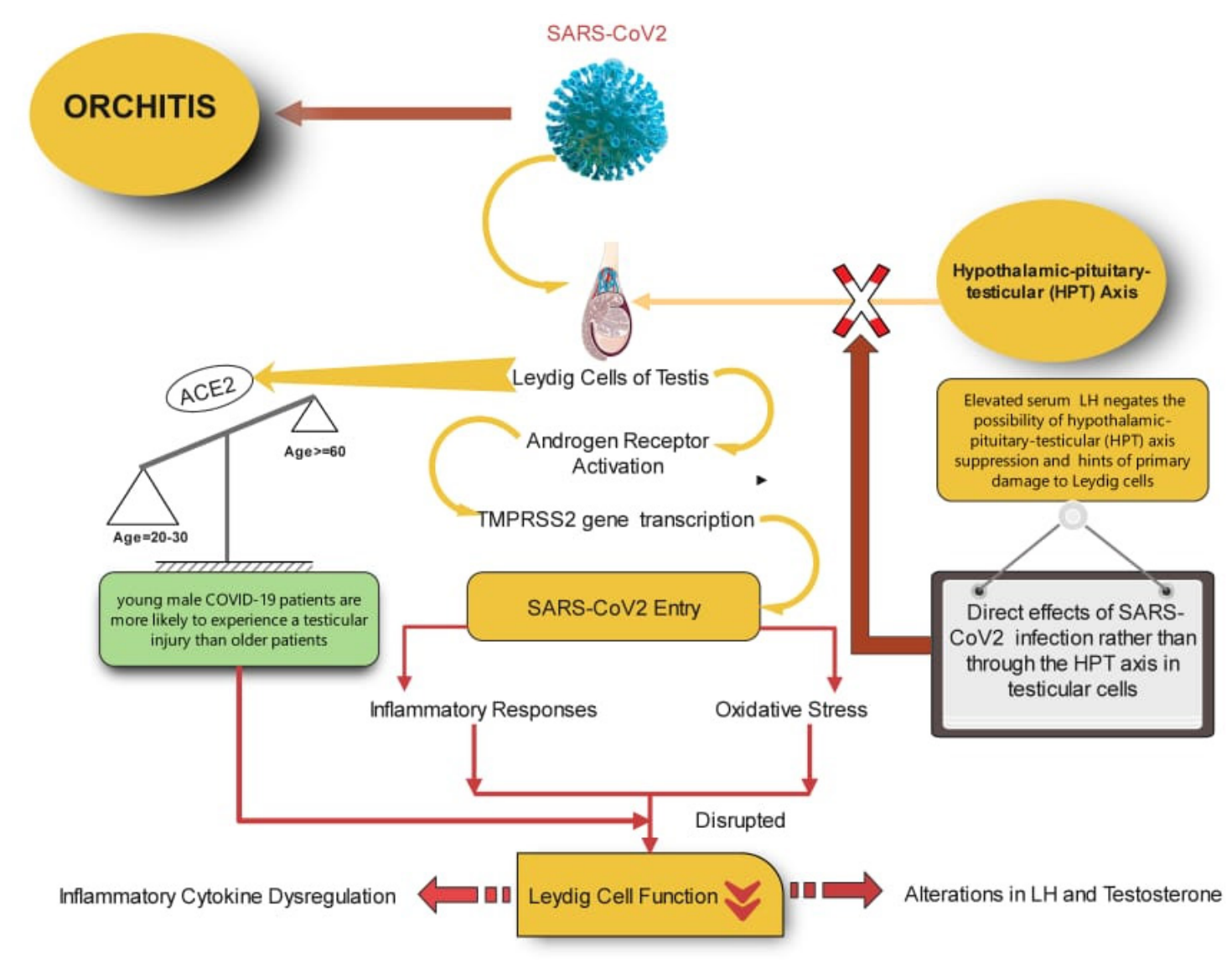

Fig. 3. Possible effect of SARS-CoV-2 on the male reproductive system. SARS-CoV-2: severe acute respiratory syndrome coronavirus 2; TMPRSS2: transmembrane protease/serine subfamily member 2; ACE2: angiotensin-converting enzyme 2; HPT axis: hypothalamicpituitary-testicular axis; LH: luteinizing hormone.

\section{Conclusions}

Endocrine activity with COVID-19 remains largely unexplored despite the continuing pandemic. At this point in time, the above data pertaining to COVID-19 and the endocrine system and steroidogenesis is mostly conjectural and factual, though, this study focuses on shedding some light into the problematic. Validated conclusions must not be drawn on the basis of the data provided, as many of the results are based on previous SARS experience and recent literature from small-scale studies. In this pandemic situation, it is crucial to ensure that rigorous and adequate clinical trials are performed to clarify the exact underlying mechanisms how COVID-19 is associated with steroidogenesis and fertility. The knowledge does, however, provide sufficient space for future study. Endocrinologists in clinical practice will need to pay more attention to these possibilities, as premature as it may sound, particularly while dealing with COVID-19 survivors.

\section{Conflict of Interest}

There is no conflict of interest.

\section{Acknowledgements}

This work was financially supported by the Scientific Agency of the Slovak Republic VEGA No. 1/0083/21, No. $1 / 0038 / 19$, No. $1 / 0163 / 18$ and by the Slovak Research and Development Agency Grant APVV-200218, APVV-19-0243, APVV-18-0312.

\section{References}

AKBAS EM, AKBAS N: COVID-19, adrenal gland, glucocorticoids, and adrenal insufficiency. Biomed Pap Med Fac Univ Palacky Olomouc Czech Repub 165: 1-7, 2021. https://doi.org/10.5507/bp.2021.011 
ALMASRY SM, HASSAN ZA, ELSAED WM, ELBASTAWISY YM: Structural evaluation of the peritubular sheath of rat's testes after administration of ribavirin: A possible impact on the testicular function. Int J Immunopathol Pharmacol 30: 282-296, 2017. https://doi.org/10.1177/0394632017726261

BARBAGALlO F, CALOGERO AE, CANNARELlA R, CONDORELLI RA, MONGIOİ LM, AVERSA A, LA VIGNERA S: The testis in patients with COVID-19: virus reservoir or immunization resource? Transl Androl Urol 9: 1897-1900, 2020. https://doi.org/10.21037/tau-20-900

BELLASTELLA G, MAIORINO MI, ESPOSITO K: Endocrine complications of COVID-19: what happens to the thyroid and adrenal glands? J Endocrinol Invest 43: 1897-1900, 2020. https://doi.org/10.1007/s40618-020-01311-8

BHAGAVATHULA AS, ALDHALEEI W, ROVETTA A, RAHMANI J: Vaccines and drug therapeutics to lock down novel coronavirus disease 2019 (COVID-19): A systematic review of clinical trials. Cureus 12: e8342, 2020. https://doi.org/10.7759/cureus.8342

BOST P, GILADI A, LIU Y, BENDJELAL Y, XU G, DAVID E, BLECHER-GONEN R, COHEN M, MEDAGLIA C, LI H, DECZKOWSKA A, ZHANG S, SCHWIKOWSKI B, ZHANG Z, AMIT I: Host-viral infection maps reveal signatures of severe COVID-19 patients. Cell 181: 1475-1488.e12, 2020. https://doi.org/10.1016/j.cell.2020.05.006

BURRELL AJ, PELLEGRINI B, SALIMI F, BEGUM H, BROADLEY T, CAMPBELL LT, CHENG AC, CHEUNG W, COOPER DJ, EARNEST A, ERICKSON SJ, FRENCH CJ, KALDOR JM, LITTON E, MURTHY S, MCALLISTER RE, NICHOL AD, PALERMO A, PLUMMER MP, RAMANAN M, ET AL.: Outcomes for patients with COVID-19 admitted to Australian intensive care units during the first four months of the pandemic. Med J Aust 214: 23-30, 2021. https://doi.org/10.5694/mja2.50883

CARDONA MAYA WD, DU PLESSIS SS, VELILLA PA: SARS-CoV-2 and the testis: similarity with other viruses and routes of infection. Reprod Biomed Online 40: 763-764, 2020. https://doi.org/10.1016/j.rbmo.2020.04.009

CASCELLA M, RAJNIK M, ALEEM A, DULEBOHN CS, DI NAPOLI R: Features, evaluation, and treatment of coronavirus (COVID-19). StatPearls [Internet], 2021. https://pubmed.ncbi.nlm.nih.gov/32150360/

CATTRINI C, BERSANELLI M, LATOCCA MM, CONTE B, VALLOME G, BOCCARDO F: Sex hormones and hormone therapy during COVID-19 pandemic: Implications for patients with cancer. Cancers 12: 2325, 2020. https://doi.org/10.3390/cancers12082325

CHANNAPPANAVAR R, FETT C, MACK M, TEN EYCK PP, MEYERHOLZ DK, PERLMAN S: Sex-based differences in susceptibility to severe acute respiratory syndrome coronavirus infection. J Immunol 198: 4046-4053, 2017. https://doi.org/10.4049/jimmunol.1601896

CHEN Y, GUO Y, PAN Y, ZHAO ZJ: Structure analysis of the receptor binding of 2019-nCoV. Biochem Biophys Res Commun 525: 135-140, 2020. https://doi.org/10.1016/j.bbrc.2020.02.071

DING Y, WANG H, SHEN H, LI Z, GENG J, HAN H, CAI J, LI X, KANG W, WENG D, LU Y, WU D, HE L, YAO K: The clinical pathology of severe acute respiratory syndrome (SARS): a report from China. J Pathol 200: 282-289, 2003. https://doi.org/10.1002/path.1440

DOUGLAS GC, O'BRYAN MK, HEDGER MP, LEE DKL, YARSKI MA, SMITH AI, LEW RA: The novel Angiotensin-Converting Enzyme (ACE) homolog, ACE2, is selectively expressed by adult Leydig cells of the Testis. Endocrinology 145: 4703-4711, 2004. https://doi.org/10.1210/en.2004-0443

DUARTE-NETO AN, MONTEIRO RAA, SILVA LFF, MALHEIROS DMAC, OLIVEIRA EP, THEODORO-FILHO J, PINHO JRR, GOMES-GOUVÊA MS, SALLES APM, OLIVEIRA IRS, MAUAD T, SALDIVA PHN, DOLHNIKOFF M: Pulmonary and systemic involvement in COVID-19 patients assessed with ultrasound-guided minimally invasive autopsy. Histopathology 77: 186-197, 2020. https://doi.org/10.1111/his.14160

DUTTA S, SENGUPTA P: SARS-CoV-2 infection, oxidative stress and male reproductive hormones: can testicularadrenal crosstalk be ruled-out? J Basic Clin Physiol Pharmacol 31: 20200205, 2020. https://doi.org/10.1515/jbcpp-2020-0205

DUTTA S, SENGUPTA P: SARS-CoV-2 and male infertility: Possible multifaceted pathology. Reprod Sci 28: 23-26, 2021. https://doi.org/10.1007/s43032-020-00261-z

ESAKANDARI H, NABI-AFJADI M, FAKKARI-AFJADI J, FARAHMANDIAN N, MIRESMAEILI S-M, BAHREINI E: A comprehensive review of COVID-19 characteristics. Biol Proced Online 22: 19, 2020. https://doi.org/10.1186/s12575-020-00128-2 
FAN C, LU W, LI K, DING Y, WANG J: ACE2 Expression in kidney and testis may cause kidney and testis infection in COVID-19 patients. Front Med (Lausanne) 7: 563893, 2021. https://doi.org/10.3389/fmed.2020.563893

FAN Y, ZHAO K, SHI Z-L, ZHOU P: Bat coronaviruses in China. Viruses 11: 210, 2019. https://doi.org/10.3390/v11030210

FREIRE SANTANA M, BORBA MGS, BAÍA-DA-SILVA DC, VAL F, ALEXANDRE MAA, BRITO-SOUSA JD, MELO GC, QUEIROGA MVO, LEÃO FARIAS ME, CAMILO CC, NAVECA FG, XAVIER MS, MONTEIRO WM, AUGUSTO PIVOTO JOÃO G, HAJJAR LA, ORDI J, LACERDA MVG, FERREIRA LCL: Case Report: Adrenal Pathology Findings in Severe COVID-19: An Autopsy Study. Am J Trop Med Hyg 103: 1604-1607, 2020. https://doi.org/10.4269/ajtmh.20-0787

FU J, ZHOU B, ZHANG L, BALAJI KS, WEI C, LIU X, CHEN H, PENG J, FU J: Expressions and significances of the angiotensin-converting enzyme 2 gene, the receptor of SARS-CoV-2 for COVID-19. Mol Biol Rep 47: 4383-4392, 2020. https://doi.org/10.1007/s11033-020-05478-4

GHAEBI M, OSALI A, VALIZADEH H, ROSHANGAR L, AHMADI M: Vaccine development and therapeutic design for 2019-nCoV/SARS-CoV-2: Challenges and chances. J Cell Physiol 235: 9098-9109, 2020. https://doi.org/10.1002/jep.29771

GHEBLAWI M, WANG K, VIVEIROS A, NGUYEN Q, ZHONG J-C, TURNER AJ, RAIZADA MK, GRANT MB, OUDIT GY: Angiotensin-converting enzyme 2: SARS-CoV-2 receptor and regulator of the renin-angiotensin system. Circ Res 126: 1456-1474, 2020. https://doi.org/10.1161/CIRCRESAHA.120.317015

GLOWACKA I, BERTRAM S, MULLER MA, ALLEN P, SOILLEUX E, PFEFFERLE S, STEFFEN I, TSEGAYE TS, HE Y, GNIRSS K, NIEMEYER D, SCHNEIDER H, DROSTEN C, POHLMANN S: Evidence that TMPRSS2 activates the severe acute respiratory syndrome coronavirus spike protein for membrane fusion and reduces viral control by the humoral immune response. J Virology 85: 4122-4134, 2011. https://doi.org/10.1128/JVI.02232-10

GRIFFITH DM, SHARMA G, HOLLIDAY CS, ENYIA OK, VALLIERE M, SEMLOW AR, STEWART EC, BLUMENTHAL RS: Men and COVID-19: A biopsychosocial approach to understanding sex differences in mortality and recommendations for practice and policy interventions. Prev Chronic Dis 17: E63, 2020. https://doi.org/10.5888/pcd17.200247

GU J, KORTEWEG C: Pathology and pathogenesis of severe acute respiratory syndrome. Am J Pathol 170: 1136-1147, 2007. https://doi.org/10.2353/ajpath.2007.061088

GUAN W, NI Z, HU Y, LIANG W, OU C, HE J, LIU L, SHAN H, LEI C, HUI DSC, DU B, LI L, ZENG G, YUEN KY, CHEN R, TANG C, WANG T, CHEN P, XIANG J, ET AL.: Clinical characteristics of coronavirus disease 2019 in China. New Engl J Med 382: 711-712, 2020. https://doi.org/10.1056/NEJMoa2002032

GUARNOTTA V, FERRIGNO R, MARTINO M, BARBOT M, ISIDORI AM, SCARONI C, FERRANTE A, ARNALDI G, PIVONELLO R, GIORDANO C: Glucocorticoid excess and COVID-19 disease. Rev Endocr Metab Disord 2020: 1-12, 2020. https://doi.org/10.1007/s11154-020-09598-X

GUO Y-R, CAO Q-D, HONG Z-S, TAN Y-Y, CHEN S-D, JIN H-J, TAN K-S, WANG D-Y, YAN Y: The origin, transmission and clinical therapies on coronavirus disease 2019 (COVID-19) outbreak - an update on the status. Mil Med Res 7: 11, 2020. https://doi.org/10.1186/s40779-020-00240-0

GUPTA S, SHARMA R, AGARWAL A, PAREKH N, FINELLI R, SHAH R, KANDIL H, SALEH R, ARAFA M, KO E, SIMOPOULOU M, ZINI A, RAJMIL O, KAVOUSSI P, SINGH K, AMBAR RF, ELBARDISI H, SENGUPTA P, MARTINEZ M, ET AL.: A comprehensive guide to sperm recovery in infertile men with retrograde ejaculation. World J Mens Health 39: e29, 2021. https://doi.org/10.5534/wjmh.210069

HE F, DENG Y, LI W: Coronavirus disease 2019: What we know? J Med Virol 92: 719-725, 2020. https://doi.org/10.1002/jmv.25766

HOFFMANN M, KLEINE-WEBER H, SCHROEDER S, KRÜGER N, HERRLER T, ERICHSEN S, SCHIERGENS TS, HERRLER G, WU N-H, NITSCHE A, MÜLLER MA, DROSTEN C, PÖHLMANN S: SARS-CoV-2 cell entry depends on ACE2 and TMPRSS2 and is blocked by a clinically proven protease inhibitor. Cell 181: 271-280.e8, 2020. https://doi.org/10.1016/j.cell.2020.02.052

HOLTMANN N, EDIMIRIS P, ANDREE M, DOEHMEN C, BASTON-BUEST D, ADAMS O, KRUESSEL J-S, BIELFELD AP: Assessment of SARS-CoV-2 in human semen-a cohort study. Fertil Steril 114: 233-238, 2020. https://doi.org/10.1016/j.fertnstert.2020.05.028 
HONORATO-SAMPAIO K, PEREIRA VM, SANTOS RAS, REIS AM: Evidence that angiotensin-(1-7) is an intermediate of gonadotrophin-induced oocyte maturation in the rat preovulatory follicle. Exp Physiol 97: 642-650, 2012. https://doi.org/10.1113/expphysiol.2011.061960

JAYAWARDENA N, BURGA LN, POIRIER JT, BOSTINA M: Virus-receptor interactions: Structural insights for oncolytic virus development. Oncolytic Virother 8: 39-56, 2019. https://doi.org/10.2147/OV.S218494

JHA N, JEYARAMAN M, RACHAMALLA M, OJHA S, DUA K, CHELLAPPAN D, MUTHU S, SHARMA A, JHA S, JAIN R, JEYARAMAN N, GS P, SATYAM R, KHAN F, PANDEY P, VERMA N, SINGH S, ROYCHOUDHURY S, ET AL.: Current understanding of novel coronavirus: molecular pathogenesis, diagnosis, and treatment approaches. Immuno 1: 30-66, 2021. https://doi.org/10.3390/immuno1010004

JING Y, RUN-QIAN L, HAO-RAN W, HAO-RAN C, YA-BIN L, YANG G, FEI C: Potential influence of COVID19/ACE2 on the female reproductive system. Mol Hum Reprod 26: 367-373, 2020. https://doi.org/10.1093/molehr/gaaa030

KYROU I, KARTERIS E, ROBBINS T, CHATHA K, DRENOS F, RANDEVA HS: Polycystic ovary syndrome (PCOS) and COVID-19: an overlooked female patient population at potentially higher risk during the COVID19 pandemic. BMC Med 18: 220, 2020. https://doi.org/10.1186/s12916-020-01697-5

LAM TT-Y, JIA N, ZHANG Y-W, SHUM MH-H, JIANG J-F, ZHU H-C, TONG Y-G, SHI Y-X, NI X-B, LIAO Y-S, LI W-J, JIANG B-G, WEI W, YUAN T-T, ZHENG K, CUI X-M, LI J, PEI G-Q, QIANG X, ET AL.: Identifying SARS-CoV-2-related coronaviruses in Malayan pangolins. Nature 583: 282-285, 2020. https://doi.org/10.1038/s41586-020-2169-0

LI K, CHEN G, HOU H, LIAO Q, CHEN J, BAI H, LEE S, WANG C, LI H, CHENG L, AI J: Analysis of sex hormones and menstruation in COVID-19 women of child-bearing age. Reprod Biomed Online 42: 260-267, 2021. https://doi.org/10.1016/j.rbmo.2020.09.020

LI W, SUI J, HUANG I-C, KUHN JH, RADOSHITZKY SR, MARASCO WA, CHOE H, FARZAN M: The S proteins of human coronavirus NL63 and severe acute respiratory syndrome coronavirus bind overlapping regions of ACE2. Virology 367: 367-374, 2007. https://doi.org/10.1016/j.virol.2007.04.035

LOTFI M, HAMBLIN MR, REZAEI N: COVID-19: Transmission, prevention, and potential therapeutic opportunities. Clin Chim Acta 508: 254-266, 2020. https://doi.org/10.1016/j.cca.2020.05.044

LÜ M, QIU L, JIA G, GUO R, LENG Q: Single-cell expression profiles of ACE2 and TMPRSS2 reveals potential vertical transmission and fetus infection of SARS-CoV-2. Aging 12: 19880-19897, 2020. https://doi.org/10.18632/aging.104015

MA L, XIE W, LI D, SHI L, MAO Y, XIONG Y, ZHANG Y, ZHANG M: Effect of SARS-CoV-2 infection upon male gonadal function: A single center-based study. MedRxiv, 2020. https://doi.org/10.1101/2020.03.21.20037267

MADJUNKOV M, DVIRI M, LIBRACH C: A comprehensive review of the impact of COVID-19 on human reproductive biology, assisted reproduction care and pregnancy: a Canadian perspective. J Ovarian Res 13: 140, 2020. https://doi.org/10.1186/s13048-020-00737-1

MAGGIO M, BASARIA S, CEDA G, BLE A, LING S, BANDINELLI S, VALENTI G, FERRUCCI L: The relationship between testosterone and molecular markers of inflammation in older men. J Endocrinol Invest 28 (11 Suppl Proceedings): 116-119, 2005.

MAO Y, XU B, GUAN W, XU D, LI F, REN R, ZHU X, GAO Y, JIANG L: The adrenal cortex, an underestimated site of SARS-CoV-2 infection. Front Endocrinol 11: 593179, 2021. https://doi.org/10.3389/fendo.2020.593179

MAUVAIS-JARVIS F, KLEIN SL, LEVIN ER: Estradiol, progesterone, immunomodulation, and COVID-19 outcomes. Endocrinology 161: bqaa127, 2020. https://doi.org/10.1210/endocr/bqaa127

MENG Y, WU P, LU W, LIU K, MA K, HUANG L, CAI J, ZHANG H, QIN Y, SUN H, DING W, GUI L, WU P: Sex-specific clinical characteristics and prognosis of coronavirus disease-19 infection in Wuhan, China: A retrospective study of 168 severe patients. PLoS Pathogens 16: e1008520, 2020. https://doi.org/10.1371/journal.ppat.1008520

MOHAMAD N-V, WONG SK, WAN HASAN WN, JOLLY JJ, NUR-FARHANA MF, IMA-NIRWANA S, CHIN K-Y: The relationship between circulating testosterone and inflammatory cytokines in men. Aging Male 22: 129-140, 2019. https://doi.org/10.1080/13685538.2018.1482487 
MOLLICA V, RIZZO A, MASSARI F: The pivotal role of TMPRSS2 in coronavirus disease 2019 and prostate cancer. Future Oncol 16: 2029-2033, 2020. https://doi.org/10.2217/fon-2020-0571

MONTOPOLI M, ZUMERLE S, VETTOR R, RUGGE M, ZORZI M, CATAPANO CV, CARBONE GM, CAVALLI A, PAGANO F, RAGAZZI E, PRAYER-GALETTI T, ALIMONTI A: Androgen-deprivation therapies for prostate cancer and risk of infection by SARS-CoV-2: a population-based study $(\mathrm{N}=4532)$. Ann Oncol 31: 1040-1045, 2020. https://doi.org/10.1016/j.annonc.2020.04.479

NARAYANA K, D'SOUZA UJA, SEETHARAMA RAO KP: Ribavirin-induced sperm shape abnormalities in Wistar rat. Mutat Res 513: 193-196, 2002. https://doi.org/10.1016/S1383-5718(01)00308-4

NAVARRA A, ALBANI E, CASTELLANO S, ARRUZZOLO L, LEVI-SETTI PE: Coronavirus disease-19 infection: Implications on male fertility and reproduction. Front Physiol 11: 574761, 2020. https://doi.org/10.3389/fphys.2020.574761

NI L, YE F, CHENG M-L, FENG Y, DENG Y-Q, ZHAO H, WEI P, GE J, GOU M, LI X, SUN L, CAO T, WANG P, ZHOU C, ZHANG R, LIANG P, GUO H, WANG X, QIN C-F, ET AL.: Detection of SARS-CoV-2-specific humoral and cellular immunity in COVID-19 convalescent individuals. Immunity 52: 971-977.e3, 2020. https://doi.org/10.1016/j.immuni.2020.04.023

PACES J, STRIZOVA Z, SMRZ D, CERNY J: COVID-19 and the Immune System. Physiol Res 69: 379-388, 2020. https://doi.org/10.33549/physiolres.934492

PAL R, BANERJEE M: COVID-19 and the endocrine system: exploring the unexplored. J Endocrinol Invest 43: 1027-1031, 2020. https://doi.org/10.1007/s40618-020-01276-8

PARASKEVIS D, KOSTAKI EG, MAGIORKINIS G, PANAYIOTAKOPOULOS G, SOURVINOS G, TSIODRAS S: Full-genome evolutionary analysis of the novel corona virus (2019-nCoV) rejects the hypothesis of emergence as a result of a recent recombination event. Infect Genet Evol 79: 104212, 2020. https://doi.org/10.1016/j.meegid.2020.104212

PIVONELLO R, AURIEMMA RS, PIVONELLO C, ISIDORI AM, CORONA G, COLAO A, MILLAR RP: Sex disparities in COVID-19 severity and outcome: Are men weaker or women stronger? Neuroendocrinology 2020, 1-20, 2020. https://doi.org/10.1159/000513346

POZZILLI P, LENZI A: Commentary: Testosterone, a key hormone in the context of COVID-19 pandemic. Metabolism 108: 154252, 2020. https://doi.org/10.1016/j.metabol.2020.154252

PUGGIONI G, PINTUS D, MELZI E, MELONI G, ROCCHIGIANI AM, MAESTRALE C, MANUNTA D, SAVINI G, DATTENA M, OGGIANO A, PALMARINI M, LIGIOS C: Testicular degeneration and infertility following arbovirus infection. J Virol 92: e01131-18, 2018. https://doi.org/10.1128/JVI.01131-18

RASTRELLI G, DI STASI V, INGLESE F, BECCARIA M, GARUTI M, DI COSTANZO D, SPREAFICO F, GRECO GF, CERVI G, PECORIELLO A, MAGINI A, TODISCO T, CIPRIANI S, MASEROLI E, CORONA G, SALONIA A, LENZI A, MAGGI M, DE DONNO G, VIGNOZZI L: Low testosterone levels predict clinical adverse outcomes in SARS-CoV-2 pneumonia patients. Andrology 9: 88-98, 2021. https://doi.org/10.1111/andr.12821

ROYCHOUDHURY S, DAS A, JHA NK, KESARI KK, ROYCHOUDHURY S, JHA SK, KOSGI R, CHOUDHURY AP, LUKAC N, MADHU NR, KUMAR D, SLAMA P: Viral pathogenesis of SARS-CoV-2 infection and male reproductive health. Open Biol 11: 200347, 2021a. https://doi.org/10.1098/rsob.200347

ROYCHOUDHURY S, DAS A, SENGUPTA P, DUTTA S, ROYCHOUDHURY S, CHOUDHURY AP, AHMED ABF, BHATTACHARJEE S, SLAMA P: Viral pandemics of the last four decades: Pathophysiology, health impacts and perspectives. Int J Environ Res Public Health 17: 9411, 2020. https://doi.org/10.3390/ijerph17249411

ROYCHOUDHURY S, DAS A, SENGUPTA P, DUTTA S, ROYCHOUDHURY S, KOLESAROVA A, HLEBA L, MASSANYI P, SLAMA P: Viral pandemics of twenty-first century. J Microbiol Biotechnol Food Sci 10: 711-716, 2021b. https://doi.org/10.15414/jmbfs.2021.10.4.711-716

SENGUPTA P, DUTTA S: COVID-19 and hypogonadism: secondary immune responses rule-over endocrine mechanisms. Hum Fertil (Camb) 2021, 1-6, 2021. https://doi.org/10.1080/14647273.2020.1867902

SHEN Q, XIAO X, AIERKEN A, YUE W, WU X, LIAO M, HUA J: The ACE2 expression in Sertoli cells and germ cells may cause male reproductive disorder after SARS-CoV-2 infection. J Cell Mol Med 24: 9472-9477, 2020. https://doi.org/10.1111/jcmm.15541 
SILVEIRA MM, MOREIRA GMSG, MENDONÇA M: DNA vaccines against COVID-19: Perspectives and challenges. Life Sci 267: 118919, 2021. https://doi.org/10.1016/j.lfs.2020.118919

SIMMONS G, ZMORA P, GIERER S, HEURICH A, PÖHLMANN S: Proteolytic activation of the SARS-coronavirus spike protein: Cutting enzymes at the cutting edge of antiviral research. Antiviral Res 100: 605-614, 2013. https://doi.org/10.1016/j.antiviral.2013.09.028

SINGH B, GORNET M, SIMS H, KISANGA E, KNIGHT Z, SEGARS J: Severe acute respiratory syndrome coronavirus 2 (SARS-CoV-2) and its effect on gametogenesis and early pregnancy. Am J Reprod Immunol 84: e13351, 2020. https://doi.org/10.1111/aji.13351

SONG H, SEDDIGHZADEH B, COOPERBERG RM, HUANG WF: EXPRESSION of ACE2, the SARS-CoV-2 receptor, and TMPRSS2 in prostate epithelial cells. Eur Urol 78: 296-298, 2020. https://doi.org/10.1101/2020.04.24.056259

STANLEY KE, THOMAS E, LEAVER M, WELLS D: Coronavirus disease-19 and fertility: viral host entry protein expression in male and female reproductive tissues. Fertil Steril 114: 33-43, 2020. https://doi.org/10.1016/j.fertnstert.2020.05.001

VAN DAMME W, DAHAKE R, DELAMOU A, INGELBEEN B, WOUTERS E, VANHAM G, VAN DE PAS R, DOSSOU J-P, IR P, ABIMBOLA S, VAN DER BORGHT S, NARAYANAN D, BLOOM G, VAN ENGELGEM I, AG AHMED MA, KIENDRÉBÉOGO JA, VERDONCK K, DE BROUWERE V, BELLO K, ET AL.: The COVID-19 pandemic: diverse contexts; different epidemics-how and why? BMJ Global Health 5: e003098, 2020. https://doi.org/10.1136/bmjgh-2020-003098

VANDERRIELE P-E, CAROCCIA B, SECCIA TM, PIAZZA M, LENZINI L, TORRESAN F, IACOBONE M, UNGER T, ROSSI GP: The angiotensin type 2 receptor in the human adrenocortical zona glomerulosa and in aldosterone-producing adenoma: Low expression and no functional role. Clin Sci (Lond) 132: 627-640, 2018. https://doi.org/10.1042/CS20171593

VAŠKŮ A: Covid-19 infection and the host genetic predisposition: Does it exist? Physiol Res 69: 511-514, 2020. https://doi.org/10.33549/physiolres.934504

WALLS AC, PARK Y-J, TORTORICI MA, WALL A, MCGUIRE AT, VEESLER D: Structure, function, and antigenicity of the SARS-CoV-2 spike glycoprotein. Cell 181: 281-292.e6, 2020. https://doi.org/10.1016/j.cell.2020.02.058

WANG Q, ZHANG Y, WU L, NIU S, SONG C, ZHANG Z, LU G, QIAO C, HU Y, YUEN K-Y, WANG Q, ZHOU H, YAN J, QI J: Structural and functional basis of SARS-CoV-2 entry by using human ACE2. Cell 181: 894-904.e9, 2020a. https://doi.org/10.1016/j.cell.2020.03.045

WANG S, ZHOU X, ZHANG T, WANG Z: The need for urogenital tract monitoring in COVID-19. Nat Rev Urol 17: 314-315, 2020b. https://doi.org/10.1038/s41585-020-0319-7

WHEATLAND R: Molecular mimicry of ACTH in SARS - implications for corticosteroid treatment and prophylaxis. Med Hypotheses 63: 855-862, 2004. https://doi.org/10.1016/j.mehy.2004.04.009

WHO: Coronavirus disease (COVID-19) 2021a. https:/www.who.int/emergencies/diseases/novel-coronavirus2019/question-and-answers-hub/q-a-detail/coronavirus-disease-covid-19\#: :text=symptoms

WHO: Coronavirus disease (COVID-19) pandemic 2021b. https://www.who.int/emergencies/diseases/novelcoronavirus-2019? gclid=CjwKCAjwoZWHBhBgEiwAiMN66YX90yrcvVQneULZyU87ekQkZrVPt9785tLITbBSFGWA_L_nvVbnhoCG10QAvD_BwE

WHO: WHO Coronavirus (COVID-19) Dashboard 2021c, July. https://covid19.who.int/

WRAPP D, WANG N, CORBETT KS, GOLDSMITH JA, HSIEH C-L, ABIONA O, GRAHAM BS, MCLELLAN JS: Cryo-EM structure of the 2019-nCoV spike in the prefusion conformation. Science 367: 1260-1263, 2020. https://doi.org/10.1126/science.abb2507

WU F, ZHAO S, YU B, CHEN Y-M, WANG W, SONG Z-G, HU Y, TAO Z-W, TIAN J-H, PEI Y-Y, YUAN M-L, ZHANG Y-L, DAI F-H, LIU Y, WANG Q-M, ZHENG J-J, XU L, HOLMES EC, ZHANG Y-Z: Author Correction: A new coronavirus associated with human respiratory disease in China. Nature 580: E7, 2020. https://doi.org/10.1038/s41586-020-2202-3

WU K, LI W, PENG G, LI F: Crystal structure of NL63 respiratory coronavirus receptor-binding domain complexed with its human receptor. Proc Natl Acad Sci U S A 106: 19970-19974, 2009. https://doi.org/10.1073/pnas.0908837106

XU J, QI L, CHI X, YANG J, WEI X, GONG E, PEH S, GU J: Orchitis: A complication of severe acute respiratory syndrome (SARS). Biol Reprod 74: 410-416, 2006. https://doi.org/10.1095/biolreprod.105.044776 
XU X-W, WU X-X, JIANG X-G, XU K-J, YING L-J, MA C-L, LI S-B, WANG H-Y, ZHANG S, GAO H-N, SHENG J-F, CAI H-L, QIU Y-Q, LI L-J: Clinical findings in a group of patients infected with the 2019 novel coronavirus (SARS-Cov-2) outside of Wuhan, China: retrospective case series. BMJ 368: m606, 2020. https://doi.org/10.1136/bmj.m606

YAN R, ZHANG Y, LI Y, XIA L, GUO Y, ZHOU Q: Structural basis for the recognition of SARS-CoV-2 by full-length human ACE2. Science 367: 1444-1448, 2020. https://doi.org/10.1126/science.abb2762

YANG X, YU Y, XU J, SHU H, XIA J, LIU H, WU Y, ZHANG L, YU Z, FANG M, YU T, WANG Y, PAN S, ZOU X, YUAN S, SHANG Y: Clinical course and outcomes of critically ill patients with SARS-CoV-2 pneumonia in Wuhan, China: a single-centered, retrospective, observational study. Lancet Respir Med 8: 475-481, 2020. https://doi.org/10.1016/S2213-2600(20)30079-5

ZHANG H, LI H-B, LYU J-R, LEI X-M, LI W, WU G, LYU J, DAI Z-M: Specific ACE2 expression in small intestinal enterocytes may cause gastrointestinal symptoms and injury after 2019-nCoV infection. Int J Infect Dis 96: 19-24, 2020a. https://doi.org/10.1016/j.ijid.2020.04.027

ZHANG H, PENNINGER JM, LI Y, ZHONG N, SLUTSKY AS: Angiotensin-converting enzyme 2 (ACE2) as a SARS-CoV-2 receptor: molecular mechanisms and potential therapeutic target. Intensive Care Med 46: 586-590, 2020b. https://doi.org/10.1007/s00134-020-05985-9

ZHOU P, YANG X-L, WANG X-G, HU B, ZHANG L, ZHANG W, SI H-R, ZHU Y, LI B, HUANG C-L, CHEN H-D, CHEN J, LUO Y, GUO H, JIANG R-D, LIU M-Q, CHEN Y, SHEN X-R, WANG X, ET AL:: A pneumonia outbreak associated with a new coronavirus of probable bat origin. Nature 579: 270-273, 2020. https://doi.org/10.1038/s41586-020-2012-7 